\title{
Review
}

\section{Sensitivity of the Early Life Stages of Macroalgae from the Northern Hemisphere to Ultraviolet Radiation ${ }^{\dagger}$}

\author{
Michael Y. Roleda ${ }^{\star 1,2}$, Christian Wiencke ${ }^{3}$, Dieter Hanelt ${ }^{4}$ and Kai Bischof ${ }^{5}$ \\ ${ }^{1}$ Biologische Anstalt Helgoland, Alfred Wegener Institute for Polar and Marine Research, Marine Station, \\ Helgoland, Germany \\ ${ }^{2}$ Institut für Polarökologie, University of Kiel, Kiel, Germany \\ ${ }^{3}$ Alfred Wegener Institute for Polar and Marine Research, Section Seaweed Biology, Bremerhaven, Germany \\ ${ }^{4}$ Biozentrum Klein Flottbek, University of Hamburg, Hamburg, Germany \\ ${ }^{5}$ Department of Marine Botany, University of Bremen, Bremen, Germany \\ Received 17 August 2006; accepted 3 October 2006; published online 10 October 2006; DOI: 10.1562/2006-08-17-IR-1005
}

\section{ABSTRACT}

The reproductive cells of macroalgae are regarded as the life history stages most susceptible to various environmental stresses, including UV radiation (UVR). UVR is proposed to determine the upper depth distribution limit of macroalgae on the shore. These hypotheses were tested by UV-exposure experiments, using spores and young thalli of the eulittoral Rhodophyceae Mastocarpus stellatus and Chondrus crispus and various sublittoral brown macroalgae (Phaeophyceae) with different depth distribution from Helgoland (German Bight) and Spitsbergen (Arctic). In spores, the degree of UV-induced inhibition of photosynthesis is lower in eulittoral species and higher in sublittoral species. After UV stress, recovery of photosynthetic capacity is faster in eulittoral compared to sublittoral species. DNA damage is lowest while repair of DNA damage is highest in eulittoral compared to sublittoral species. When the negative impact of UVR prevails, spore germination is inhibited. This is observed in deep water kelp species whereas the same UVR doses do not inhibit germination of shallow water kelp species. A potential acclimation mechanism to increase $U V$ tolerance of brown algal spores is the species-specific ability to increase the content of $\mathrm{UV}$-absorbing phlorotannins in response to $\mathrm{UV}$ exposure. Growth rates of young Mastocarpus and Chondrus gametophytes exposed to experimental doses of UVR are not affected while growth rates of all young kelp sporophytes exposed to UVR are significantly lowered. Furthermore, morphological UV damage in Laminaria ochroleuca includes tissue deformation, lesion, blistering and thickening of the meristematic part of the lamina. The sensitivity of young sporophytes to DNA damage is correlated with thallus thickness and their optical characteristics. Growth rate is an integrative parameter of all physiological processes in juvenile plants. UV inhibition of growth may affect the upper distribution depth limit of adult life history stages. Juveniles possess several mechanisms to minimize

\footnotetext{
$\dagger$ This invited paper is part of the symposium-in-print: UV Effects in Aquatic an Terrestrial Environments.

*Corresponding author email: mroleda@ipoe.uni-kiel.de (Michael Y. Roleda) (C) 2007 The Authors. Journal Compilation. The American Society of Photobiology 0031-8655/07
}

UVR damage and, hence, are less sensitive but at the expense of growth. The species-specific susceptibility of the early life stages of macroalgae to UVR plays an important role for the determination of zonation patterns and probably also for shaping up community structure.

\section{INTRODUCTION}

Marine macroalgae or seaweeds play important ecological roles as the nutritional base in marine communities, both in the rocky intertidal and subtidal zones. The lush blades of canopyforming underwater kelps and their labyrinth holdfast support different marine communities by providing food for herbivores, a physical structure for shelter, protection from predators and nurseries for many marine animals.

Ecological effects of global environmental changes, particularly global warming and the increase in UVR caused by ozone depletion still raise considerable concern. In the last 20 years, the effects of increasing UVR on aquatic primary production and its role in shaping seaweed community and depth distribution limits have been extensively studied $(1,2)$. However, most of these studies were conducted on adult plants.

Physiological studies on the early life stages of macroalgae in response to environmental stress are wanting. Upon release, propagules of different macroalgal species can be suspended in the water column by turbulent mixing. Within the euphotic layer, they are potentially exposed to high solar radiation. Residence time in the water column, sinking velocity and their capability to cope with light stress can influence spore viability. Surviving propagules can then be laterally dispersed by currents across the expanse of the vertical littoral zone. Settled spores at great depths or under algal canopies receive low light levels suitable for germination and growth. Settlement in the eulittoral zone can expose new recruits to air during low tides and to the whole spectrum of solar radiation, which may contribute to the postrecruitment mortality and exclude sensitive species from higher positions on the shore.

Survival of early transitional life history stages (e.g. spores, sporelings and germlings) is therefore the most critical phase 
leading to the successful formation of benthic populations and determines the upper depth distribution limits of the adult life history stages (3-5). Susceptibility to UVR can, however, be counterbalanced by protection strategies such as avoidance, screening, photochemical quenching and repair (6). Avoidance strategies include habitat selection by recruiting under the canopy of adult sporophytes, circadian rhythms by phasing cellular activities sensitive to light at night (7), seasonality of reproduction and diel periodicity in spore release $(8,9)$. UVscreening includes extracellular (cell wall) and intracellular mechanisms (UV-absorbing compounds). UV-absorbing compounds include mycosporine-like amino acids (MAAs), phlorotannins and scytonemin which partially provide screening against UV-A and UV-B, and are found in Rhodophyta, Phaeophyta and cyanobacteria, respectively (10-12). UV-B induced DNA damage is repaired through photo-reactivating light (13).

This review focuses on the physiological constraints of the early life stages of representative red and brown macroalgae on the Helgoland and Spitsbergen shoreline. The effect of UVR was measured on several physiological responses such as photosynthesis, germination, growth, DNA damage and repair and synthesis of UV-absorbing compounds. Empirical data are presented to support our hypothesis that the susceptibility of the early life history stages to UVR may determine the upper depth distribution limit of the mature sporophytes.

\section{BIOGEOGRAPHIC DISTRIBUTION AND ZONATION PATTERN}

Mastocarpus stellatus Stackhouse (Guiry) and Chondrus crispus Stackhouse are morphologically similar and closely related representatives of the red algal order Gigartinales, distributed along the North Atlantic coast and co-inhabit the rocky eulittoral and upper sublittoral zone (14). In the sublittoral, distribution of kelps on Helgoland is characterized by the occurrence of Laminaria digitata (Hudson) Lamouroux in the upper sublittoral whereas L. saccharina (Linnaeus) Lamouroux and L. hyperborea (Gunnerus) Foslie grow in the mid and lower sublittoral, respectively (Fig. 1a). The southern distribution of Laminaria ochroleuca de la Pylaie is reported along the coast of South and North Atlantic $(15,16)$, and the Mediterranean (17).

Seaweeds in the Arctic have a circumpolar distribution and most species are also found throughout the temperate North Atlantic (14). The kelp forest of Kongsfjorden, Spitsbergen (Svalbard) is structured by the annual kelp-like Saccorhiza dermatodea (Bachelot de la Pylaie) J. E. Areschoug (Tilopteridales), and the perennial Laminariales Alaria esculenta (Linnaeus) Greville, L. digitata and L. saccharina growing in this sequence down to about $10 \mathrm{~m}$ (18). The endemic Arctic species L. solidungula J. Agardh occurs predominantly in the inner zone of the fjord at great depths (Fig. 1b).

Recruitment of macroalgae in coastal environments can be influenced by several abiotic stress factors such as temperature, solar radiation, nutrients and their synergistic effects $(19,20)$. Their survival is further controlled by demographic factors, competitors and grazers $(21,22)$, and a combination of both abiotic and biotic factors (23). Stress tolerance and survival strategy is therefore important in shaping up the community structure and zonation pattern.
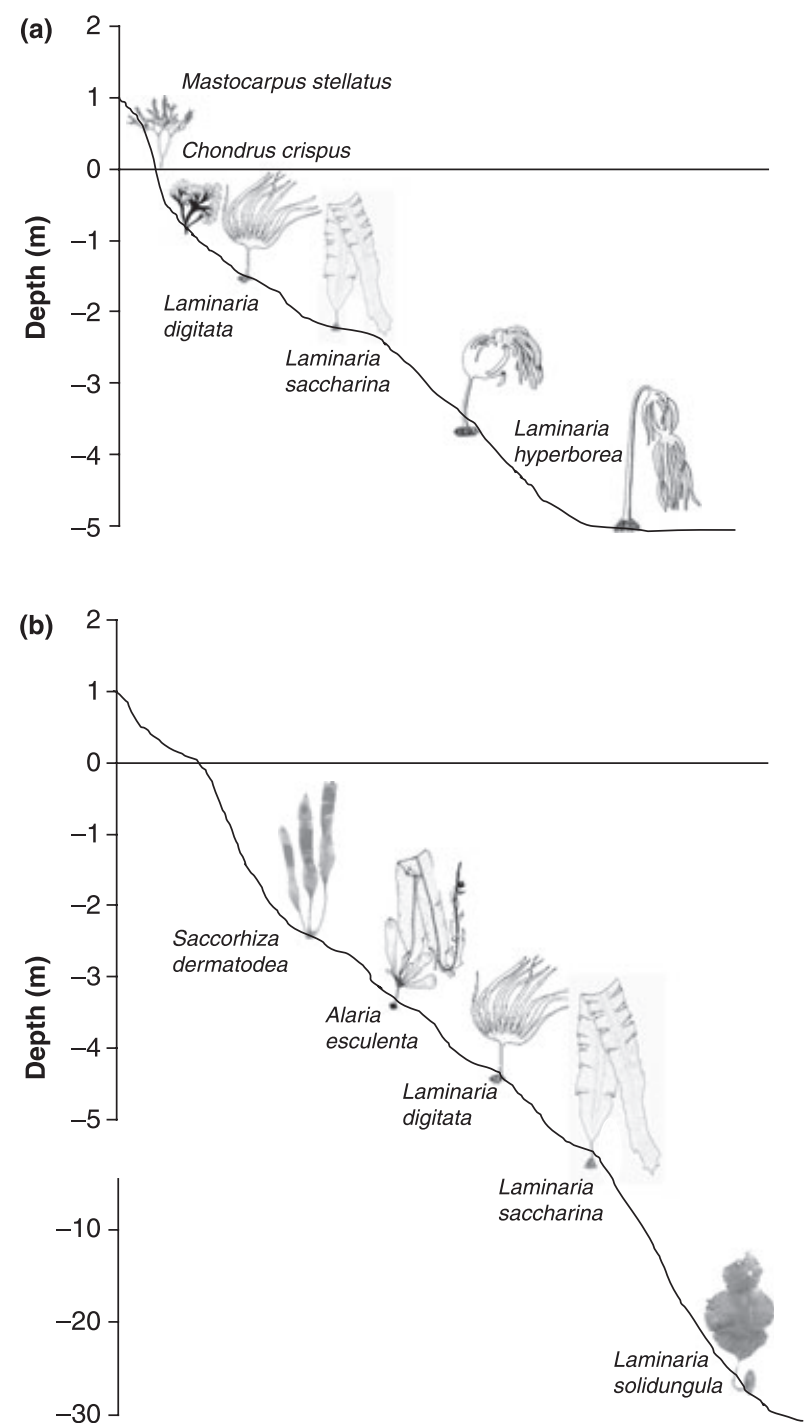

Figure 1. Upper depth distribution of investigated macroalgal species in Helgoland, North Sea (a) and Kongsfjorden, Svalbard (b).

\section{LIFE HISTORY}

Seaweed life histories follow different patterns. Most red seaweeds have a complex triphasic life history involving the alternation of generation consisting of gametophytic, carposporophytic and tetrasporophytic stages. Carposporophytes are minute plantlets or life history stages formed inside the female gametophyte after fertilization. The red alga $M$. stellatus has a heteromorphic life history where the nonmotile carpospore produces a crustose tetrasporophytic crust previously referred to the genus Petrocelis (24). In C. crispus, the tetrasporophytic and gametophytic generations are isomorphic. A typical alternation of a haploid gametophyte with a diploid carposporophyte, and a diploid tetrasporophyte is indicated in this species (25).

Large brown seaweeds of the order Laminariales have a heteromorphic life history with an alternation of macroscopic sporophytes and microscopic gametophytes. The sporophyte develops sporangia which divide meiotically producing flagellated haploid zoospores. Zoospores are released and upon 
settlement develop into microthalli which bear the gametangia. Sexual reproduction involves signalling chemicals that induce sperm release from antheridia and subsequent chemotactic orientation of sperms towards the luring eggs $(26,27)$. Sporophytes are differentiated into holdfast, stipe and lamina while gametophytes are undifferentiated and are filamentous and creeping.

\section{UV RADIATION AND HIGH LIGHT STRESS}

Solar radiation is the primary source of energy for photoautotrohic organisms to synthesize organic compounds. Photosynthesis is a dynamic process which can acclimate to variations in light intensity and spectral quality $(28,29)$. Short-term light fluctuations elicit fast and reversible reactions such as fluorescence or heat dissipation, e.g. via the xanthophyll cycle which is considered a major photoprotective process, or energy redistribution between the two photosystems (30). Under long-term light stress, proteins specific for light-induced stresses in photosynthetic organisms (early lightinduced proteins) play a role in photoprotection (31). Antioxidant enzymes, lipid-soluble antioxidants inside cellular membranes (e.g. carotenoids), and water-soluble reductants found in the cytosol are defenses against forms of reactive oxygen (32).

Under strong light, photo-oxidative damage impairs the function of PSII. Photodamage is controlled by the steadystate oxidation-reduction level of the primary quinone acceptor $\left(\mathrm{Q}_{\mathrm{A}}\right)$. As the reduction state of $\mathrm{Q}_{\mathrm{A}}$ linearly increases with irradiance, the probability of photodamage increases under strong light (33). While light damages PSII directly, oxidative stress during photosynthesis has been demonstrated to suppress the de novo synthesis of proteins, in particular, newly synthesized D1 protein, which is required for the exchange of the damaged reaction center protein in PSII $(34,35)$. Photodamage mainly occurs in seaweeds growing in the lower sublittoral zone when exposed to high irradiances. These species have a lower ability to downregulate photosynthesis through photoprotection or photoregulation processes (36).

Since the detection of stratospheric ozone depletion over Antarctica in the early 1980s, a yearly net springtime loss of $60-70 \%$ had been a recurring phenomenon that intensifies ambient UV-B radiation on the biosphere $(37,38)$. Moreover, the area affected by ozone depletion has expanded to five-fold over the past decades in continental Antarctica. In the Arctic, springtime stratospheric ozone depletion was also detected recently at a less severe loss of up to $\sim 20-25 \%(39,40)$. Ozone loss of $\sim 6 \%$ has also been reported in the mid latitudes (41). The increasing UVR on the earth's surface caused by stratospheric ozone depletion has been documented in the polar and temperate regions $(42,43)$.

The underwater UV environment in Helgoland and Kongsfjorden has been distinctly characterized. The seawater at Helgoland strongly attenuates UV-B radiation so that the $1 \%$ depth for $305 \mathrm{~nm}$ radiation is at $1 \mathrm{~m}$ during spring and summer. Measurements with a biospherical spectrometer showed that the $1 \%$ depths for UV-A wavelengths at 320 , 340 and $380 \mathrm{~nm}$ are 2.0, 2.6 and $4.6 \mathrm{~m}$, respectively (44). This is attributed to the high phytoplankton stocks in coastal North Sea water (45) and the strong tide flows and currents also contribute to the re-suspension of sediments (46). During
Arctic spring in Kongsfjorden, the water body is in comparison much clearer and the $1 \%$ depth of UV-B radiation can even be at about $13 \mathrm{~m}$ depth (47). However, as UV-irradiance impinging on the water surface in the Arctic is much lower than at the temperate Helgoland, the threshold irradiance still affecting plant productivity was only at about 5-6 $\mathrm{m}$ depth in spring, comparable to the biologically-weighted $1 \%$ UV-B penetration (4-7 m) reported by Wiencke et al. (4). Melt-water input during Arctic summer increases water turbidity and UVR attenuation so that the $1 \%$ level also decreases to about $6 \mathrm{~m}$ depth (47).

UV-B radiation has several effects on the physiology and productivity of marine macrophytes. The negative impact of exposure to UVR includes: inhibition of photosynthesis and eventual photodamage to the photosynthetic apparatus (48); protein breakdown and the loss of specific enzymatic or biological function (49); damage to microtubules causing inhibition of nuclear division (50); formation of cyclobutane pyrimidine dimers (CPDs) in the DNA, inhibiting genome replication and expression $(13,51)$; absorption by aromatic sulfhydryl-containing biomolecules causing direct molecular damage (52); and production of reactive oxygen species responsible for oxidative damage within the cell (53).

\section{PHOTOSYNTHESIS OF REPRODUCTIVE CELLS}

The physiology of light harvesting, changes in photosynthetic efficiency and kinetics of photosynthetic recovery in spores were measured by in vivo fluorescence changes of photosystem II $(5,54,55)$. Spores isolated from plants inhabiting different tidal zones were found to be low light adapted. Saturation irradiance of freshly released spores of different kelp species showed minimal $I_{\mathrm{k}}$ values (photon fluence rate where initial slope intersects horizontal asymptote of the curve) values ranging from $20-40 \mu \mathrm{mol}$ photons $\mathrm{m}^{-2} \mathrm{~s}^{-1}$ among temperate species (5) and 13-18 $\mu \mathrm{mol}$ photons $\mathrm{m}^{-2} \mathrm{~s}^{-1}$ among Arctic species $(55)$. Furthermore, optimum quantum yields $\left(F_{\mathrm{v}} / F_{\mathrm{m}}\right)$ of Gigartinales carpospores and Laminariales zoospores decreased already after $1 \mathrm{~h}$ exposure to photon flux densities (PFD) of 56 and only $22 \mu \mathrm{mol}$ photons $\mathrm{m}^{-2} \mathrm{~s}^{-1}$ PAR, respectively $(5,54)$. Increasing dose of PAR, as a function of exposure time, further depressed the $F_{\mathrm{v}} / F_{\mathrm{m}}$. Across the different light treatments, the highest photosynthetic efficiency was observed in the eulittoral $C$. crispus and lowest in the sublittoral Laminaria hyperborea (Fig. 2).

Ultraviolet radiation contributes significantly to photoinhibition and no recovery was observed in the photosynthetic efficiency of spores exposed to highest UV-A and UV-B doses among the lower sublittoral temperate $L$. hyperborea from Helgoland (Fig. 2) and Arctic L. saccharina from Kongsfjorden (55). The first attempt to study the kinetics of photosynthetic recovery in brown algal zoospores showed a fast phase in $S$. dermatodea which indicates a reduction in the photoprotective process while a slow phase in L. saccharina indicates recovery from severe photodamage (55). Differences in P (PAR), PA (PAR + UV-A) and PAB (PAR + UV-A + UV-B) sensitivity of optimum quantum yield are presumably caused by the degree of damage to PSII components versus the xanthophyll cycle-mediated downregulation of PSII (56). UV radiation depresses photosynthetic performance mainly by damaging the 

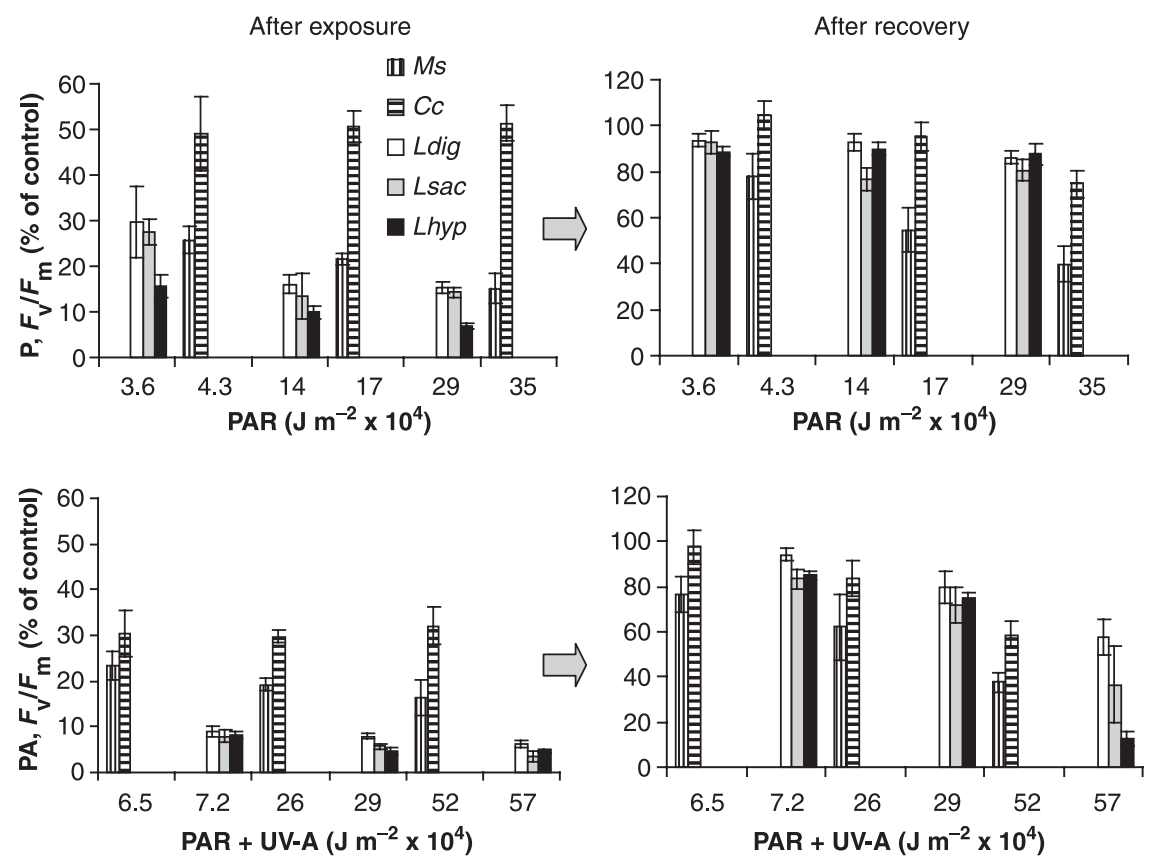

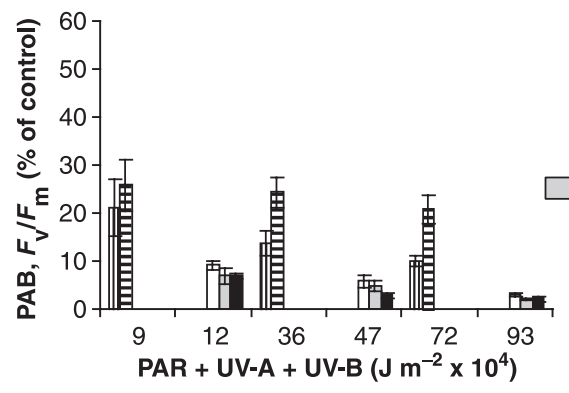

Exposure dose

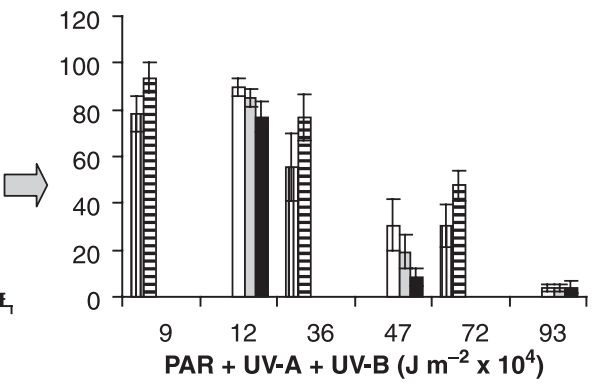

Exposure dose of treatment
Figure 2. Mean optimum quantum yield $\left(F_{\mathrm{v}} / F_{\mathrm{m}}\right)$ of spores during treatment (left column) to different doses of photosynthetically active radiation $(\mathrm{PAR}=\mathrm{P}), \mathrm{PAR}+\mathrm{UV}-\mathrm{A}(\mathrm{PA})$ and PAR + UV-A + UV-B (PAB) in Mastocarpus stellatus (Ms), Chondrus crispus $(C c)$, Laminaria digitata (Ldig), L. saccharina (Lsac) and L. hyperborea (Lhyp) expressed as percentage of control. Corresponding photosynthetic recovery (right column) after $48 \mathrm{~h}$ postculture in dim white light $(10 \mu \mathrm{mol}$ photon $\left.\mathrm{m}^{-2} \mathrm{~s}^{-1}\right)$. Vertical bars are standard deviations (SD, $N=5$ ). Composite of and modified from Refs. $(5,54)$. oxidizing site and reaction center of Photosystem II $(12,57,58)$. Slow photosynthetic recovery can reduce the accumulation of photosynthetic products disabling cellular division and delaying the initiation of germination in reproductive cells.

\section{PHOTOSYNTHESIS OF JUVENILE SEAWEEDS}

Unlike spores, photosynthetic efficiencies of juvenile seaweeds exposed to experimental irradiance of PAR alone were not photoinhibited while a decrease in photosynthetic efficiencies was also observed in juvenile plants exposed to PAR supplemented with UV-A and UV-A + UV-B (54,59). Partial and complete acclimation to UVR by repeated exposure was, however, observed in juvenile plants of L. ochroleuca and in M. stellatus (Fig. 3) and C. crispus (54) respectively. Acclimation of photosynthesis to UVR has been previously reported in sporophytes of Arctic Laminariales $(60,61)$. Among different kelp species, the higher susceptibility of the deep sea species to photoinhibition is attributed to its limited de-epoxidation capacity and reduced xanthophyll-cycle pool size compared to the shallow water species (62).

In Mastocarpus and Chondrus, the complete acclimation of photosynthesis in young gametophytes of these species after
3 days of repeated UVR exposure (54) contradicts the previous study of Bischof et al. (63). They reported a reduction in photoinhibition but no acclimation throughout the 5 days repeated exposure to $\mathrm{PAB}$. This difference may be attributed to the higher experimental UV irradiance used in their study, which was twice the intensity applied here. PAR:UV-B ratios in both experiments are unrealistic.

UV-B radiation has more direct effects on the photosynthetic apparatus. Part of the D1/D2 heterodimer, the major structural complex within PSII are degraded (64). Inactivation of oxygen-evolving complex is induced by blue light as well as UV light while red light inactivates the photochemical reaction center (65). UV-A radiation, on the other hand, was found to be damaging for PSII by decreasing the electron flow from reaction centers to plastoquinone (58) affecting electron transport both at the water oxidizing complex and the binding site of the $\mathrm{Q}_{\mathrm{B}}$ quinine electron acceptor (57). UVR is also reported to decrease the pool size of carbon fixation enzymes such as carbonic anhydrase (66) and ribulose-1, 5-bisphosphate carboxylase/oxygenase (Rubisco) $(67,68)$. Although some algae are able to partially acclimate to chronic UVR exposure, growth and tissue morphology can be affected under UVR exposure (59). 
Figure 3. Time series of the circadian pattern of the mean effective quantum yield $\left(\Delta F / F_{\mathrm{m}}{ }^{\prime}\right)$ of juvenile sporophytes and gametophytes during the light phase of the 16:8 h light:dark photoperiod. PFD is $40-50 \mu \mathrm{mol}$ photons $\mathrm{m}^{-2} \mathrm{~s}^{-1}$. Vertical bars are standard deviations ( $\mathrm{SD}, N=5$ ). Composite of and modified from Refs. $(54,59)$.

\section{Laminaria ochroleuca}

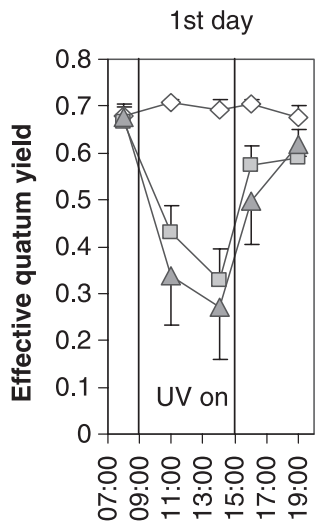

Mastocarpus stellatus

1st day

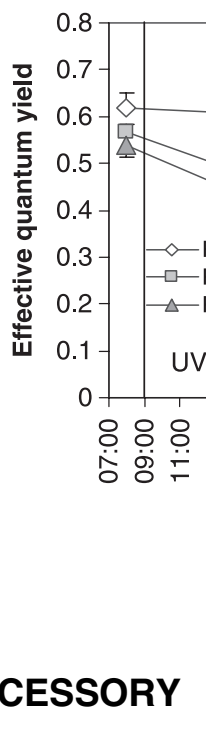

\section{PIGMENTS}

PHOTOSYNTHETIC AND ACCESSORY

Sensitivity of photosynthetic and accessory pigments to UVR is species specific and dose dependent. Chlorophyll $a$ contents in both eulittoral species Mastocarpus and Chondrus were not negatively affected by UVR but instead showed an increasing content when PAR was supplemented with UV-A and UV-A + UV-B (54). Among the different kelp species investigated, significantly lower pigment concentrations ( $\mathrm{Chl} a$, $\mathrm{Chl}$ $c_{1}$, fucoxanthin and $\beta$-carotene) were observed in young $L$. ochroleuca sporophytes exposed to $1.1 \times 10^{4} \mathrm{~J} \mathrm{~m}^{-2}$ daily UVR dose (59). Young Laminariales sporophytes from Helgoland and Spitsbergen exposed to $0.9 \times 10^{4} \mathrm{~J} \mathrm{~m}^{-2}$ daily UVR dose showed insignificant differences in $\mathrm{Chl} a$ contents compared to plants exposed to PAR alone (69-71). The insignificant differences between treatments suggests that the young sporophytes were able to synthesize new pigments to replace degraded chlorophylls. However, in situ seasonal variation in pigment concentration of Arctic L saccharina collected before, during and after ice break up showed decreasing chlorophyll $a$ concentration coinciding with increasing underwater radiation. Chlorophyll $a$ concentration did not increase when melting snow contributed to water turbidity and reduction in underwater radiation (72) suggesting irreparable degradation of pigments after exposure to high light intensity or photo-

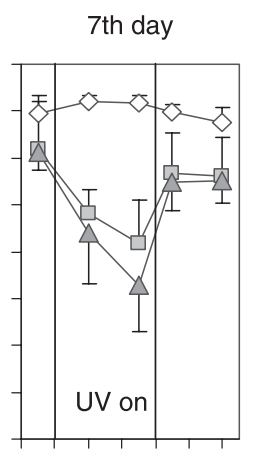

88.88 .8

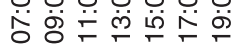

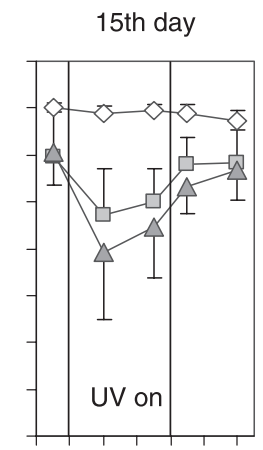

8888888

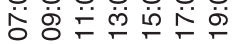

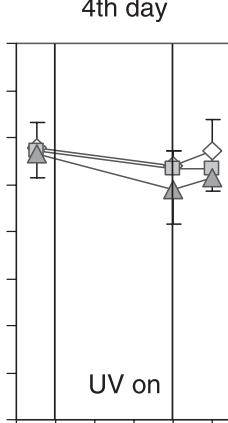

8 8 8 8 8 8 今े 7th day

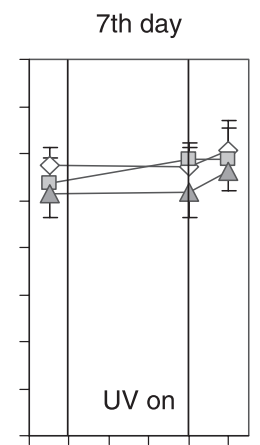

888888 官官宅

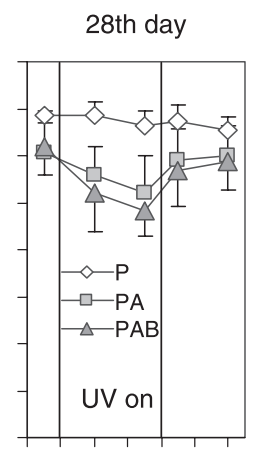
穴守芹

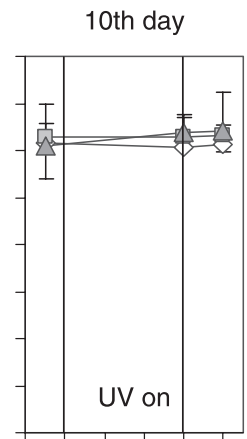

888888

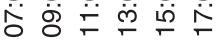

88.8888

Time of day

adaptation of light absorption. Field material collected on Spitsbergen showed bleaching of young L. saccharina recruits at $4 \mathrm{~m}$ depth after prolonged exposure to ambient solar radiation during sea-ice break up (S. Kremb, personal communication). Pigment damage can result either (1) when protein-based pigments absorb UV energy directly and undergo photochemical degradation; (2) by photosensitizer action; or (3) oxygen radical production in addition to singlet oxygen (6).

Accessory pigments such as carotenoids are involved in several aspects of photosynthesis such as light absorption and energy transfer to the reaction center complex and protection of the photosynthetic apparatus from damage by strong illumination. In Chondrus, the higher contents of total carotenoids measured under PAB (54) could be related to its photoprotective role (73). Accumulation of carotenoids specifically in response to UV radiation has been reported in cyanobacteria and chlorophytes $(74,75)$. This mechanism can protect the photosynthetic apparatus facilitating acclimation of photosynthesis and growth to UVR. Among Laminariales, the tissue absorption peaks in the Soret region $(400-540 \mathrm{~nm}$ ) (69-71) are characteristic of carotenoids in antenna complexes of higher plants $(76,77)$. Among the natural solar radiationacclimated young wild sporophytes, the higher absorption in this region could imply some photoprotective role of carotenoids. 


\section{PHYSODES AND UV-ABSORBING COMPOUNDS IN SPORES}

Spectral analysis of zoospore suspensions of the three Helgolandic Laminaria species (5) and the Arctic $S$. dermatodea, A. esculenta and L. digitata showed strong absorption in the UV waveband (78) characteristic of phlorotannins. The occurrence of phenolic compounds in reproductive cells of brown algae has been previously reported (79-81). The absorption spectra show an increasing absorbance from $300 \mathrm{~nm}$ to the shorter UV-C waveband comparable to that of isolated phlorotannins from Fucus gardneri Silva exhibiting a peak at $265 \mathrm{~nm}$ (82). This compound was invoked to play a role in UV protection because its synthesis is inducible by UVR (11,83). Induction of phlorotannin synthesis in kelp zoospores is, however, species specific and is not only inducible by UV-B radiation but also by PAR and UV-A $(78,84, \mathrm{M}$. Y. Roleda, C. Wiencke and U. H. Lüder unpublished).

Additional microscopic observations showed an increase in the number and size of phlorotannin-containing physodes after UV exposure in $S$. dermatodea which contribute to UVR protection against cellular damage and enhance germination rate (3). Considering the uneven localization of UV-sunscreen within the planktonic spores (85), phlorotannin-containing physodes in zoospores provide restricted efficiency for a single cell (84). Within a plume of zoospores, however, each cell can screen each other and protect the lower layer of spores from excessive radiation (78). Exudation of phlorotannins from macroalgal tissue released into seawater can also reduce the impact of UV-B exposure to UV-sensitive kelp meiospores (86). Although exocytosis of phlorotannin-containing physodes from $S$. dermatodea zoospores into the medium was not microscopically observed, the increase in absorption after exposure to PA and PAB compared to $\mathrm{P}$ and dark control shows indirect evidence of this process (84). In carpospores of Mastocarpus and Chondrus, traces of shinorine were observed (G. Kräbs and M. Y. Roleda, unpublished). Whether carpospores produce sufficient MAAs to achieve the same degree of UV protection to that of the foliose gametophytes remains to be studied.

\section{THALLUS MORPHOLOGY AND OPTICAL CHARACTERISTICS}

Increasing thallus thickness minimizes UVR effects as the outer cell layers shade inner cells and in terms of longer pathlength for UVR absorption (87). Translucence or opacity of thallus influences reflection, attenuation, scattering, absorption or transmittance of UV radiation (88). Optically dark pigmented field-grown Laminariales sporophytes show strong absorbance in the UV waveband (69-71), characteristic of the UV-absorbing phlorotannins accumulated within the outer cortical layer of the thalli of Laminariales $(89,90)$. UVR can, therefore, be attenuated by cellular UV-absorbing compounds and cell walls of the epidermal tissue effectively reducing UV fluence before reaching physiological targets. Phlorotannins are reported to have several ecological functions (11). It is known that the production of this compound (as herbivore deterrent, antibacterial agent or as UV screens) involves energy cost at the expense of growth (70). Its synthesis could be in response to specific environmental cues or stress factors and is allocated for different functions between different kelp species.

Peaks of the presumptive UV-screening substance at the UV-C region might provide no complete protection against UV-B radiation. The absorption shoulder $>265 \mathrm{~nm}$ can, however, enhance the UV-B tolerance of a plant. Furthermore, it is thought that absorption of tissue-bound phlorotannins might shift to different peaks compared to extracted compounds. Further studies are needed to address this question.

Cultured young gametophytes of $M$. stellatus are thicker than $C$. crispus (54). Initial MAA concentrations in $M$. stellatus were approximately six-fold higher than in C. crispus, among individuals of the two species collected simultaneously from the same location. After repeated UV-exposure, a $56 \%$ increase in MAAs was found in C. crispus, while in M. stellatus the concentration increased by $68 \%$. Interestingly, the MAA shinorine seems to play a crucial role in acclimation to UV-exposure, as the increase in total MAA content in $C$. crispus was almost exclusively attributed to the de novo synthesis of shinorine, which was not detected in the specimens prior to experimental UV-exposure. Moreover, shinorine was the only MAA detected in M. stellatus (63). It is assumed that the thicker thallus and higher load of MAAs in M. stellatus play a role in UV-tolerance and thus enables $M$. stellatus to proliferate at higher shore levels.

\section{UV-B-INDUCED DNA DAMAGE AND REPAIR}

The UV-sensitivity of the investigated Gigartinales carpospores and Laminariales zoospores is related to the vertical and depth distribution of the foliose gametophytes and adult sporophytes, respectively. At higher UV-B doses, lesser amounts of CPDs were observed in eulittoral species Mastocarpus and Chondrus spores compared to spores of the sublittoral kelp species (Fig. 4).

Life stage-dependent susceptibility to UV-B-induced DNA damage was observed in both groups of macroalgae tested. DNA damage occurred in carpospores of Mastocarpus and Chondrus but not in their foliose gametophytic stages. This is

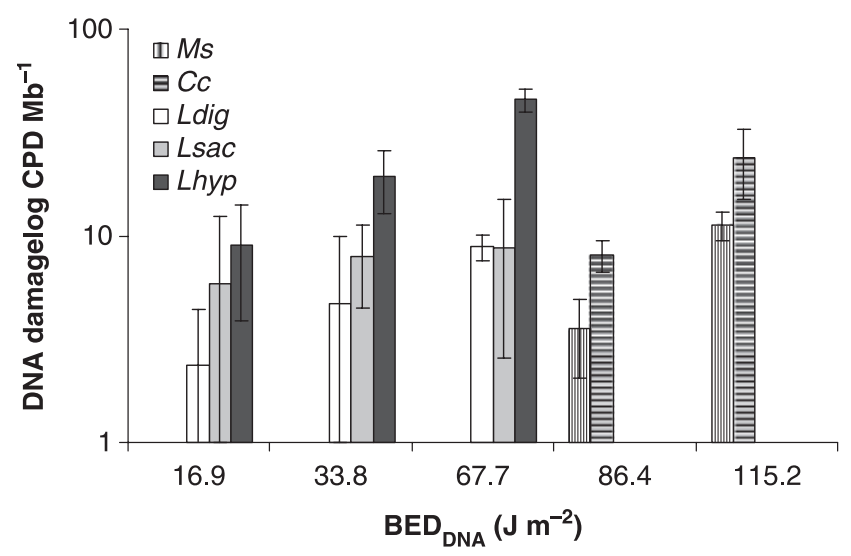

Figure 4. UV-B-induced DNA damage (induced cyclobutane pyrimidine dimers per million nucleotides) in Gigartinales carposopores and Laminariales zoospores. Species are Mastocarpus stellatus $(M s)$; Chondrus crispus (Cc); Laminaria digitata (Ldig); L. saccharina (Lsac); and L. hyperborea (Lhyp). Vertical bars are standard deviations (SD, $N=3)$. Figure redrawn from Refs. $(5,54)$. 
plausible because both species co-inhabit the eulittoral, physiologically and genetically acclimated to the full solar radiation. The lower DNA damage and effective DNA damage repair mechanism in carpospores of Mastocarpus enhance its recruitment success to the upper eulittoral zone. Zoospores of the sublittoral Laminariales from Helgoland (L. digitata, L. saccharina and L. hyperborea) (5) and Spitsbergen (A. esculenta and L. digitata) (M. Y. Roleda, C. Wiencke and U. H. Lüder, unpublished), as well as the Tilopteridales $S$. dermatodea (84) are also more susceptible to UV-B-induced DNA damage compared to young sporophytes (69-71). The numbers of CPDs observed in Helgolandic Laminaria zoospores exposed to $8 \mathrm{~h}$ UVR are $18.6 \pm 4,30.8 \pm 8$ and $49.8 \pm 6 \mathrm{CPD} \mathrm{Mb}^{-1}$ in L. digitata, L. saccharina and L. hyperborea, respectively (5). These values are higher compared to their respective young sporophytes exposed for 18-21 days of repeated $6 \mathrm{~h}$ daily UVR at $2.5 \pm 1,11.7 \pm 3$ and $3.4 \pm 2 \mathrm{CPD} \mathrm{Mb}$, respectively (71).

Among the spores investigated, less genetic damage is incurred in diploid carpospores compared to haploid zoospores. Haploid zoospores are, however, more efficient in DNA damage repair (91). In Antarctic Gigartina skottsbergii, diploid carpospores likewise incurred less UV-B-induced CPD compared to haploid tetraspores of the same species (M. Y. Roleda, unpublished). Long and Michod (92) reported that haploid cells are efficient replicators, while diploid cells are resistant to damage. Mathematical models suggest that sexual organisms can combine the advantage of both ploidy states: spending much of its life cycle in the haploid state, then fusing to become diploid. During the diploid state DNA damage can be repaired, as there are two copies of the gene in the cell and one copy is presumed to be undamaged (92). Significant removal of CPDs indicating repair of DNA damage was observed in all species investigated after recovery in low white light. DNA damage repair could either be mediated by light-dependent photolyases or light-independent nucleotide excision repair $(13,93)$ and recombination repair $(73)$.

Tissue DNA damage among juvenile Laminariales sporophytes is not related to the depth distribution of the adult sporophytes. Multicellular juvenile thalli possess several protective mechanisms to minimize UVR damage and, hence, are differentially less sensitive but at the expense of growth. The tissue CPD content is dependent on the thallus thickness (Fig. 5) and optical property (69-71). Increasing thallus thickness and opacity (in relation to available cell-bound UV-absorbing compound) minimize UVR effect where outer phlorotannin-rich cortical layer can selectively filter short UV-wavelength from reaching the UV-sensitive targets (i.e. chloroplast). An inverse relationship between thallus thickness and remaining DNA damage was observed independently between the Laminaria species from Helgoland and Spitsbergen. The lower sublittoral but thick species L. hyperborea and L. solidungula were found to have lower remaining DNA damage. UV protection through increased thallus thickness and higher content of UV-absorbing compounds led however to a growth reduction in both species. In general, there is no linear correlation between thallus thickness and DNA damage. In other species investigated, the thick but translucent $S$. dermatodea sustained more DNA damage compared to the thin but opaque $A$. esculenta and the darkly pigmented Laminaria species.

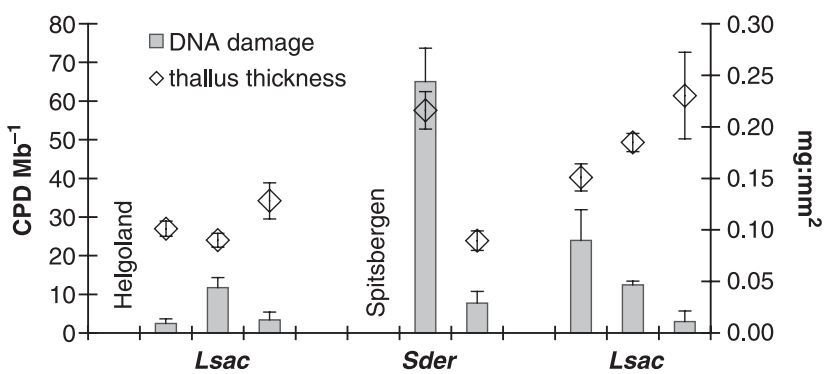

Figure 5. Relationship between average thallus thickness and remaining issue DNA damage in cultured juvenile brown macroalgal sporophytes from Helgoland and Spitsbergen after 18-21 days of repeated daily $6 \mathrm{~h}$ UVR exposure and $18 \mathrm{~h}$ recovery $(6: 8: 4 \mathrm{~h}$ light:dark:light cycle). Species are Laminaria digitata (Ldig); L. saccharina (Lsac); L. hyperborea (Lhyp); Saccorhiza dermatodea (Sder); Alaria esculenta (Aesc); and L. solidungula (Lsol). Vertical bars are standard deviations (SD, $N=3$ for DNA damage; $N=10$ for thallus thickness). Composite of and modified from Refs. (69-71).

\section{SPORE GERMINATION}

Low PFD of PAR (10-20 $\mu \mathrm{mol}$ photons $\left.\mathrm{m}^{-2} \mathrm{~s}^{-1}\right)$ is optimal for germination in spores. Germination capacity is moreover constrained by the harmful effects of UVR. Laboratory studies showed that a higher biological effective dose is needed to inhibit $50 \%$ germination rate $\left(\mathrm{BED}_{50}\right)$ in the eulittoral Mastocarpus and Chondrus (54) compared to the sublittoral Laminaria species from Helgoland (5).

Field exposure of zoospores to ambient solar radiation for 24-45 h showed that preexposure to low PAR in the laboratory and to different PFDs of high PAR in the field did not inhibit spore germination (4). This shows that spores can acclimate to a wide range of PFDs or that photosynthetic efficiency was able to recover after photoinhibition. Ecologically, the recovery process depends on the settlement of spores to suitable low-light environment. Exposure to the full solar spectrum in the water column and postcultivation in the laboratory at low-light condition, simulating low-light field microenvironment upon settlement, did not affect germination of the upper-sublittoral $S$. dermatodea. At approximately the same UV dose, germination of $A$. esculenta was susceptible to UVR while germination of the mid-sublittoral L. digitata was totally terminated. At a lower UV dose, germination of $L$. digitata was still sensitive to UVR. Persistent exposure to ambient solar radiation for an extended period of time, however, might exhibit a different effect on germination.

Results of our laboratory and field studies showed that the susceptibility of spores to UVR contributes to the determination of the upper depth distribution limit of the adult macroalgae $(3-5,55,94)$. A previous study on the susceptibility of Helgolandic Laminaria spores to UVR reported no difference between species (95). This is attributed to the two- to four-fold higher levels of UV-A and UV-B radiation that was supplemented to about $35-50 \mu \mathrm{mol}$ photons $\mathrm{m}^{-2} \mathrm{~s}^{-1}$ of PAR (UV: PAR ratio $=1.525$ ). Higher order of magnitude in UVR: PAR ratio has been reported to intensify the UV effect on plants $(96,97)$, which may magnify the effect on one species and at the same time obscure its effects between species. Comparison between experimental treatments showed that the $6 \mathrm{~h}$ UVR applied by Dring et al. (95) is equivalent to 
$3.54 \times 10^{5} \mathrm{~J} \mathrm{~m}^{-2}$, a dose higher compared to the $16 \mathrm{~h}$ PAR + UV-A + UV-B treatment $\left(3.32 \times 10^{5} \mathrm{~J} \mathrm{~m}^{-2}\right)$ applied in our study (5). Consequently, the study of Dring et al. observed lower germination rate in L. digitata (ca 20\%) and L. hyperborea $(<10 \%)$ compared to our study (UVR:PAR ratio $=1.257)$ on the same species with germination rate of $27.6 \%$ and $20.1 \%$ respectively. Higher UVR dose $(5.46 \times$ $10^{5} \mathrm{~J} \mathrm{~m}^{-2}$, UVR:PAR ratio $\left.=1.523\right)$ was also used by Wiencke et al. (3), which resulted in $<1 \%$ germination in Arctic L. digitata and L. saccharina. However, it may be possible that the Arctic population of these two Laminariales is more susceptible to UVR compared to their cold temperate counterparts.

The high UVR:PAR ratio applied in the laboratory exhibit an additional UV-B effect on photosynthesis and germination $(3,5,94)$. Higher ambient PAR in the field can enhance UV tolerance of zoospores by increasing the activity of photorepair enzymes (98). Moreover, there seems to be a UV-exposure threshold to effect a negative impact on the germination of kelp zoospores. In all species, preexposure to lower doses of ambient solar radiation at 2 and $4 \mathrm{~m}$ depths did not affect the germination capacity of zoospores. At higher doses of ambient solar radiation at 1 and $2 \mathrm{~m}$ depths, there was no additional UV-B effect on the viability of the zoospores. In all cases the viability was the same after exposure to the PA and PAB condition in the field. Damage to carbon fixation in the cells was found to be higher under the UV-A waveband in marine diatoms (58). It is further indicated that localized damage of carbon fixation on the acceptor side of the PSII reaction centers is induced by UV-A $(57,58)$.

\section{GROWTH OF JUVENILE SEAWEEDS}

Growth rates of juvenile seaweeds showed variable response to UVR. Exposure to the light spectrum did not affect growth rate of $M$. stellatus while a minimal effect was observed in $C$. crispus (Fig. 6). The growth rates of young Laminariales

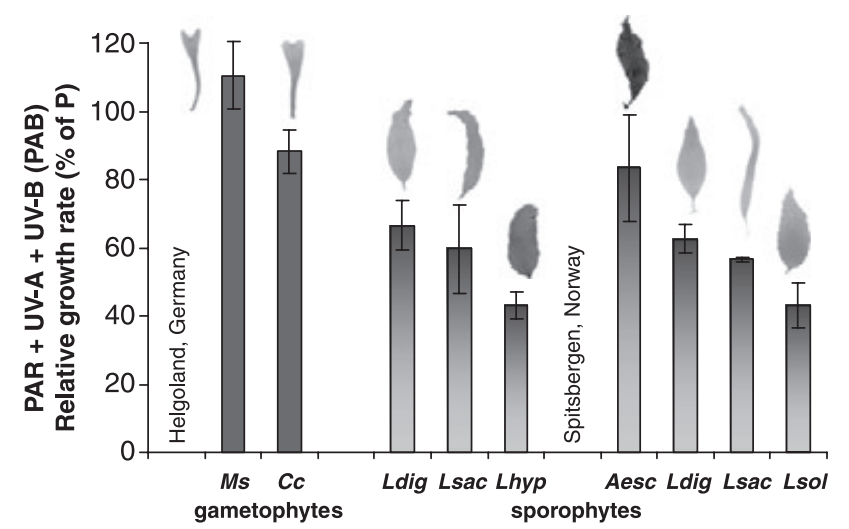

Figure 6. Growth rates in juvenile Gigartinales gametophytes and Laminariales sporophytes exposed to the whole light spectrum $(\mathrm{PAR}+\mathrm{UV}-\mathrm{A}+\mathrm{UV}-\mathrm{B})$ expressed as percent of control $(\mathrm{PAR}=$ $\mathrm{P})$. Species are Mastocarpus stellatus (Ms); Chondrus crispus $(C c)$; Laminaria digitata (Ldig); L. saccharina (Lsac); L. hyperborea (Lhyp); Alaria esculenta (Aesc); and L. solidungula ( Lsol). Inset individual thallus is typical seaweed morphology used for the experiments. Vertical bars are standard deviations (SD, $N=5$ for gametophytes; $N=3$ for sporophytes). Composite of and modified from Refs. $(54,69-71)$. sporophytes were, however, significantly reduced under UVR. The sensitivity of growth as an integrative parameter of all physiological processes shows a relation to the depth distribution pattern of the species investigated (Fig. 6).

Long-term exposure to UVR resulted in tissue deformation and damage in juvenile L. ochroleuca (59). This characteristic tissue damage and morphological deformation were still undocumented and unreported in seaweeds exposed to UVR. This is probably because previous growth studies on young Laminaria sporophytes were too short to induce tissue injury (e.g. 2-3 weeks) $(95,99)$. However, pronounced tissue necrosis and loss of parts of the thalli was reported in the Arctic Laminaria solidungula J. Agardh after 1 week of daily exposure to $18 \mathrm{~h} \mathrm{UVR}$ (100). On the other hand, UVR-induced injuries on plant tissue have been reported in terrestrial flora. This includes reduced leaf area, blistering and epidermal deformation, lesions, increased leaf thickness and photomorphogenesis (101-103). In this regard, long-term growth measurements and observation on morphological integrity of the tissue present a more holistic indication of the negative impact of the stress factor.

A simple growth model: $\mathrm{G}=\mathrm{P}-\mathrm{R}-\mathrm{L}$, follows a growth differentiation balance, where growth increment over time $(\mathrm{G})$ is a function of the rate of biomass production through gross photosynthesis $(\mathrm{P})$ and loss due to respiration $(\mathrm{R})$ and tissue loss or decay (L) (104). Under high light intensity and UVR, photoinhibition of photosynthesis already decreases potential carbon acquisition (P) into plant dry matter $(G)$ (105). Dark respiration $(\mathrm{R})$ represents the energy used to synthesize new biomass (growth respiration) and that used to maintain metabolic activity (maintenance respiration). Exposure to UVR causes cellular, enzymatic and molecular damage which could further increase loss due to respiration ( $\mathrm{R}$ ) by diverting more photosynthate for repair and defense (i.e. production of secondary metabolites). Energy demands for repair and protection may divert photosynthate at the expense of growth.

\section{CONCLUSIONS AND FUTURE PERSPECTIVES}

Different studies presented in this review have shown that young gametophytes of Mastocarpus and Chondrus are less susceptible to the detrimental effects of UVR compared to their reproductive cells. Carpospores of Chondrus were, however, more sensitive to UVR compared to carpospores of Mastocarpus. The protection strategies in Mastocarpus to counterbalance UV damage contribute to its successful recruitment and colonization of the eulittoral area on Helgoland. In the sublittoral, the sensitivity of spores of the different Laminariales species studied is related to the upper depth distribution limit of the adult sporophytes in Helgoland and Spitsbergen. Among Laminaria species from Helgoland, efficient DNA damage repair and recovery of the PSII damage in the upper sublittoral L. digitata zoospores contributed to their germination success. In Spitsbergen, the same response was observed in the zoospores of the upper sublittoral $S$. dermatodea. The presence of UV-screening substance characteristic of phlorotannins further contributed an effective protection in the zoospores of the upper sublittoral species in both biogeographic regions.

Zoospores are capable of dispersal, settlement, attachment and development into new recruits across the area of the 
vertical tidal zones. Settlement of young recruits in the eulittoral is critical because they are exposed to ambient environmental stress conditions. The recruitment success of individuals growing to adult sporophytes is therefore dependent on the sensitivity or tolerance of the young Laminaria species. Juvenile Laminariales sporophytes possess several protective mechanisms to minimize UVR damage but at the expense of growth. The long-term effects of UV exposure to macroalgae are better studied by measuring growth and morphological integrity as integrative parameters of all cellular processes rather than photosynthetic performance alone.

To estimate the ecological impact of enhanced UVR, seasonal variation in solar radiation has to be related to the reproductive seasonality of kelps as well as the diel periodicity in zoospore release $(8,9)$. The distinct reproductive seasons of Helgolandic Laminaria spp. is remarkable compared to other populations of the same species. L. digitata plants from Nova Scotia are found to be fertile throughout the year (106). To ensure reproductive success, propagule production synchronized with the onset of favorable environmental conditions (e.g. light, photoperiod or temperature) (107-109). The summer reproductive season of the upper sublittoral L. digitata would suggest that sporogenic tissues as well as zoospores of this species could tolerate or possess effective protective mechanisms against high solar radiation. On the other hand, winter reproduction in the lower sublittoral $L$. hyperborea is thought to be a strategy to avoid reproductive failure due to the relative sensitivity of their zoospores to high PAR and UVR.

Despite the artificial laboratory irradiance condition used in the different studies, it was observed that UVR affects growth and the response is related to the depth distribution in the field. Synergistic effects might exist between high PAR and UV. The irradiance of the UV wavebands used in these experiments is comparable with those occurring in nature, thus, the results are worthwhile for modelling UV-effects under natural conditions even if strong PAR is missing. This study presents a piece of the puzzle which may lead to an explanation why zonation occurs in the observed pattern in the field.

Results obtained from single-factor experiments impose strict limits in making ecological inferences. Further studies should look into the interactive effects of multiple stressors. For example, environmental variables such as temperature and UVR are changing simultaneously around the globe. These two factors have been found to induce interactive and independent effects on germination and growth in the early life stages of two multicellular marine algae (110). Moreover, net biological effects of UVR, which are a function of both the rate of UVR-induced damage and the rate at which that damage is repaired, is mediated by temperature and vice versa (110). For example, DNA repair rates in Palmaria have been shown to increase with increasing temperature (93), while sensitivity of Fucus germlings to UV-B radiation is enhanced with increasing temperature (111).

The use of sunshine simulators with a realistic PAR-UV ration will yield more ecologically relevant data regarding DNA damage repair, germination and growth of early life stages of macroalgae. As the studied macroalgal species are important primary producers in inshore coastal ecosystems serving as food for herbivores and as habitats for many organisms, changes in their depth and geographic distribution under a scenario of climate change due to stratospheric ozone depletion and global warming can entail significant ecological domino effects.

\section{REFERENCES}

1. Xue, L., Y. Zhang, T. Zhang, L. An and X. Wang (2005) Effects of enhanced ultraviolet-B radiation on algae and cyanobacteria. Crit. Rev. Microbiol. 31, 79-89.

2. Bischof, K., I. Gómez, M. Molis, D. Hanelt, U. Karsten, U. Lüder, M. Y. Roleda, K. Zacher and C. Wiencke (2006) Ultraviolet radiation shapes seaweed communities. Rev. Environ. Sci. Biotechnol. 5, 141-166.

3. Wiencke, C., M. N. Clayton and M. Schoenwaelder (2004) Sensitivity and acclimation to UV radiation of zoospores from five species of Laminariales from the Arctic. Mar. Biol. 145, 31-39.

4. Wiencke, C., M. Y. Roleda, A. Gruber, M. N. Clayton and K. Bischof (2006) Susceptibility of zoospores to UV radiation determines upper depth distribution limit of Arctic kelps: Evidence through field experiments. J. Ecol. 94, 455-463.

5. Roleda, M. Y., C. Wiencke, D. Hanelt, W. H. van de Poll and A. Gruber (2005) Sensitivity of Laminariales zoospores from Helgoland to ultraviolet and photosynthetically active radiation: Implication for depth distribution and seasonal reproduction. Plant Cell Environ. 28, 466-479.

6. Vincent, W. F. and P. J. Neale (2000) Mechanisms of UV damage to aquatic organisms. In The Effects of UV Radiation in the Marine Environment (Edited by S. de Mora, S. Demers and M. Vernet), pp. 149-176. Cambridge University Press, Cambridge.

7. Suzuki, L. and C. H. Johnson (2001) Algae know the time of day: Circadian and photoperiodic programs. J. Phycol. 37, 933-942.

8. Reed, D. C., D. R. Laur and A. W. Ebeling (1988) Variation in algal dispersal and recruitment: The importance of episodic events. Ecol. Monogr. 58, 321-335.

9. Amsler, C. D. and M. Neushul (1989) Diel periodicity of spore release from the kelp Nereocystis luetkeana (Mertens) Postels et Ruprecht. J. Exp. Mar. Biol. Ecol. 134, 117-127.

10. Karsten, U., T. Sawall, D. Hanelt, K. Bischof, F.-L. Figueroa, A. Flores-Moya and C. Wiencke (1998) An inventory of UVabsorbing mycosporine-like amino acids in macroalgae from polar to warm-temperate regions. Bot. Mar. 41, 443-453.

11. Schoenwaelder, M. E. A. (2002) The occurrence and cellular significance of physodes in brown algae. Phycologia 41, 125-139.

12. Franklin, L. A., C. B. Osmond and A. W. D. Larkum (2003) Photoinhibition, UV-B and algal photosynthesis. In Photosynthesis in Algae (Edited by A. W. Larkum, S. E. Douglas and J. A. Raven), pp. 351-384. Kluwer Academic Publishers, The Netherlands.

13. van de Poll, W. H., D. Hanelt, K. Hoyer, A. G. J. Buma and A. M. Breeman (2002) Ultraviolet-B-induced cyclobutane-pyrimidine dimer formation and repair in Arctic marine macrophytes. Photochem. Photobiol. 76, 493-501.

14. Lüning, K. (1985) Meeresbotanik: Verbreitung, Ökophysiologie und Nutzung der marine Makroalgen. Georg Thieme Verlag, Stuttgart.

15. Benhissoune, S., C.-F. Boudouresque and M. Verlaque (2002) A checklist of the seaweeds of the Mediterranean and Atlantic coasts of Morocco. II. Phaeophyceae. Bot. Mar. 45, 217-230.

16. Izquierdo, J. L., I. M. Pérez-Ruzafa and T. Gallardo (2002) Effect of temperature and photon fluence rate on gametophytes and young sporophytes of Laminaria ochroleuca Pylaie. Helgol. Mar. Res. 55, 285-292.

17. Ribera, M. A., A. Gómez-Garreta, T. Gallardo, M. Cormaci, G. Furnari and G. Giaccone (1992) Check-list of Mediterranean Seaweeds. I. Fucophyceae (Warming 1884). Bot. Mar. 35, 109-130.

18. Wiencke, C., B. Vögele, N. A. Kovaltchouk and H. Hop (2004) Species composition and zonation of marine benthic macroalgae at Hansneset in Kongsfjorden, Svalbard. Ber. Polar Meeresforsch. 492, 55-62.

19. Lotze, H. K. and B. Worm (2002) Complex interaction of climatic and ecological controls on macroalgal recruitment. Limnol. Oceanogr. 47, 1734-1741. 
20. Wiencke, C., M. N. Clayton, I. Gómez, K. Iken, U. H. Lüder, C. D. Amsler, U. Karsten, D. Hanelt, K. Bischof and K. Dunton (2007) Life strategy, ecophysiology and ecology of seaweeds in polar waters. Rev. Environ. Sci. Biotechnol. 6, 95-126.

21. Dayton, P. K., M. J. Tegner, P. B. Edwards and K. L. Riser (1999) Temporal and spatial scales of kelp demography: The role of oceanographic climate. Ecol. Monogr. 69, 219-250.

22. Pfister, C. A. and M. Wang (2005) Beyond size: Matrix projection models for population where size is an incomplete descriptor. Ecology 86, 2673-2683.

23. Dethier, M. N., S. L. Williams and A. Freeman (2005) Seaweeds under stress: Manipulated stress and herbivory affect critical lifehistory functions. Ecol. Monogr. 73, 403-418.

24. Guiry, M. D. and J. A. West (1983) Life history and hybridization studies on Gigartina stellata and Petrocelis cruenta (Rhodophyta) in the North Atlantic. J. Phycol. 19, 474- 494.

25. Chen, L. C.-M. and J. McLachlan (1972) The life history of Chondrus crispus in culture. Can. J. Bot. 50, 1055-1060.

26. Müller, D. G. (1989) The role of pheromones in sexual reproduction of brown algae. In Algae as Experimental Systems (Edited by A. W. Coleman, L. J. Goff and J. R. Stein-Taylor), pp. 201-213. Alan R. Liss, New York.

27. Maier, I., C. Hertweck and W. Boland (2001) Stereochemical specificity of lamoxirene, the sperm-releasing pheromone in kelp (Laminariales, Phaeophyceae). Biol. Bull. Mar. Biol. Lab. Woods Hole 201, 121-125.

28. Senger, H. and B. Bauer (1987) The influence of light quality on adaptation and function of the photosynthetic apparatus. Photochem. Photobiol. 45, 939-946.

29. Falkowski, P. G. and J. LaRoche (1991) Acclimation to spectral irradiance in algae. J. Phycol. 27, 8-14.

30. Hall, D. O. and K. K. Rao (1994) Photosynthesis. Cambridge University Press, Cambridge.

31. Adamska, I. (1997) ELIPs - light-induced stress proteins. Physiol. Plant. 100, 794-805.

32. Dunlap, W. C. and Y. Yamamoto (1995) Small-molecule antioxidants in marine organisms: Antioxidant activity of mycosporine-glycine. Comp. Biochem. Physiol., B 112, 105-114.

33. Melis, A. (1999) Photosystem-II damage and repair cycle in chloroplasts: What modulates the rate of photodamage in vivo? Trends Plant Sci. 4, 130-135.

34. Nishiyama, Y., S. I. Allakhverdiev, H. Yamamoto, H. Hayashi and N. Murata (2004) Singlet oxygen inhibits the repair of photosystem II by suppressing the translation elongation of the D1 protein in Synechocystis sp. PCC 6803. Biochemistry 43, 11321-11330

35. Nishiyama, Y., S. I. Allakhverdiev and N. Murata (2005) Inhibition of the repair of photosystem II by oxidative stress in cyanobacteria. Photosyn. Res. 84, 1-7.

36. Hanelt, D., C. Wiencke and K. Bischof (2003) Photosynthesis in marine macroalgae. In Photosynthesis in Algae (Edited by A. W. Larkum, S. E. Douglas and J. A. Raven), pp. 413-435. Kluwer Academic Publishers, The Netherlands.

37. Crutzen, P. J. (1992) Ultraviolet on the increase. Nature 356, 104-105.

38. Herman, J. R., P. K. Bhartia, J. Ziemke, Z. Ahmad and D. Larko (1996) UV-B increases (1979-1992) from decreases in total ozone. Geophys. Res. Lett. 23, 2117-2120.

39. Müller, R., P. J. Crutzen, J.-U. Grooß, C. Brühl, J. M. Russel III, H. Gernandt, D. S. McKenna and A. F. Tuck (1997) Severe ozone loss in the Arctic during the winter of 1995-96. Nature 389, 709-712.

40. Dahlback, A. (2002) Recent changes in surface ultraviolet solar radiation and stratospheric ozone at a high Arctic site. In $U V$ Radiation and Arctic Ecosystem (Edited by D. Hessen), pp. 3-22. Springer Verlag, Berlin, Heidelberg.

41. WMO/UNEP (2002) Scientific assessment of ozone depletion: 2002. Available at http://www.wmo.ch/web/arep/reports/ o3_assess_rep_2002_front_page.html. Accessed on 5 August $20 \overline{0} 6$.

42. Solomon, S. (1999) Stratospheric ozone depletion: A review of concepts and history. Rev. Geophys. 37, 275-316.

43. Staehelin, J., N. R. P. Harris, C. Appenzeller and J. Eberhard (2001) Ozone trends: A review. Rev. Geophys. 39, 231-290.
44. Dring, M. J., A. Wagner, L. A. Franklin, R. Kuhlenkamp and K. Lüning (2001) Seasonal and diurnal variations in ultraviolet-B and ultraviolet-A irradiances at and below the sea surface at Helgoland (North Sea) over a 6-year period. Helgol. Mar. Res. 55, 3-11.

45. Franke, H.-D., F. Buchholz and K. H. Wiltshire (2004) Ecological long-term research at Helgoland (German Bight, North Sea): Retrospect and prospect-An introduction. Helgol. Mar. Res. 58, 223-229.

46. Dring, M. J. and K. Lüning (1994) Influence of spring-neap tidal cycles on the light available for photosynthesis by benthic marine plants. Mar. Ecol. Prog. Ser. 104, 131-137.

47. Hanelt, D., H. Tüg, K. Bischof, C. Groß, H. Lippert, T. Sawall and C. Wiencke (2001) Light regime in an Arctic fjord: A study related to stratospheric ozone depletion as a basis for determination of UV effects on algal growth. Mar. Biol. 138, 649-658.

48. Hanelt, D., C. Wiencke and W. Nultsch (1997) Influence of UV radiation on photosynthesis of Arctic macroalgae in the field. J. Photochem. Photobiol. B, Biol. 38, 40-47.

49. Lao, K. and A. N. Glazer (1996) Ultraviolet-B photodestruction of a light-harvesting complex. Proc. Natl Acad. Sci. U S A 93 $5258-5263$.

50. Huovinen, P. S., A. O. J. Oikari, M. R. Soimasuo and G. N. Cherr (2000) Impact of UV radiation on the early development of the giant kelp (Macrocystis pyrifera) gametophytes. Photochem. Photobiol. 72, 308-313.

51. van de Poll, W. H., A. Eggert, A. G. J. Buma and A. M. Breeman (2001) Effects of UV-B induced DNA damage and photoinhibition on growth of temperate marine red macrophytes: Habitatrelated differences in UV-B tolerance. J. Phycol. 37, 30-37.

52. Vass, I. (1997) Adverse effects of UV-B light on the structure and function of the photosynthetic apparatus. In Handbook of Photosynthesis (Edited by M. Pessarakli), pp. 931-949. Marcel Dekker Inc., New York.

53. Rijstenbil, J. W., S. M. Coelho and M. Eijsackers (2000) A method for the assessment of light-induced oxidative stress in embryos of fucoid algae via confocal laser scan microscopy. Mar. Biol. 137, 763-774.

54. Roleda, M. Y., W. H. van de Poll, D. Hanelt and C. Wiencke (2004) PAR and UVBR effects on photosynthesis, viability, growth and DNA in different life stages of two coexisting Gigartinales: Implications for recruitment and zonation pattern. Mar. Ecol. Prog. Ser. 281, 37-50.

55. Roleda, M. Y., D. Hanelt and C. Wiencke (2006) Exposure to ultraviolet radiation delays photosynthetic recovery in Arctic kelp zoospores. Photosyn. Res. 88, 311-322.

56. Gevaert, F., A. Creach, D. Davoult, A. Migne, G. Levavasseur, P. Arzel, A.-C. Holl and Y. Lemoine (2003) Laminaria saccharina photosynthesis measured in situ: Photoinhibition and xanthophylls cycle during a tidal cycle. Mar. Ecol. Prog. Ser. 247, 43-50.

57. Turcsányi, E. and I. Vass (2002) Effect of UV-A radiation on photosynthetic electron transport. Acta Biol. Szeged. 46, 171-173.

58. Grzymski, J., C. Orrico and O. M. Schofield (2001) Monochromatic ultraviolet light induced damage to Photosystem II efficiency and carbon fixation in the marine diatom Thalassiosira pseudonana (3H). Photosyn. Res. 68, 181-192.

59. Roleda, M. Y., D. Hanelt, G. Kräbs and C. Wiencke (2004) Morphology, growth, photosynthesis and pigments in Laminaria ochroleuca (Laminariales, Phaeophyta) under ultraviolet radiation. Phycologia 43, 603-613.

60. Bischof, K., D. Hanelt, H. Tüg, U. Karsten, P. E. M. Brouwer and C. Wiencke (1998) Acclimation of brown algal photosynthesis to ultraviolet radiation in Arctic coastal waters (Spitsbergen, Norway). Polar Biol. 20, 388-395.

61. Bischof, K., D. Hanelt and C. Wiencke (1999) Acclimation of maximal quantum yield of photosynthesis in the brown alga Alaria esculenta under high light and UV radiation. Plant Biol. 1, 435-444.

62. Rodrigues, M. A., C. P. dos Santos, A. J. Young, D. Strbac and D. O. Hall (2002) A smaller and impaired xanthophyll cycle makes the deep sea macroalgae Laminaria abyssalis (Phaeophy- 
ceae) highly sensitive to daylight when compared with shallow water Laminaria digitata. J. Phycol. 38, 939-947.

63. Bischof, K., G. Kräbs, D. Hanelt and C. Wiencke (2000) Photosynthetic characteristics and mycosporine-like amino acids under UV radiation: A competitive advantage of Mastocarpus stellatus over Chondrus crispus at the Helgoland shoreline? Helgol. Mar. Res. 54, 47-52.

64. Richter, M., W. Rühle and A. Wild (1990) Studies on the mechanism of Photosystem II photoinhibition I. A two-step degradation of D1-protein. Photosyn. Res. 24, 229-235.

65. Ohnishi, N., S. I. Allakhverdiev, S. Takahashi, S. Higashi, W. Watanabe, Y. Nishiyama and N. Murata (2005) Two-step mechanism of photodamage to photosystem II: Step 1 occurs at the oxygen-evolving complex and step 2 occurs at the photochemical reaction center. Biochemistry 44, 8494-8499.

66. Dionisio, M. L., M. Tsuzuki and S. Miyachi (1989) Blue light induction of carbonic anhydrase activity in Chlamydomonas reinhardtii. Plant Cell Physiol. 30, 215-219.

67. Bischof, K., D. Hanelt and C. Wiencke (2000) UV-effects on photosynthesis and related enzyme reactions of marine macroalgae. Planta 211, 555-562.

68. Bischof, K., G. Kräbs, C. Wiencke and D. Hanelt (2002) Solar ultraviolet radiation affects the activity of ribulose-1,5-biphosphate carboxylase-oxygenase and the composition of photosynthetic and xanthophyll cycle pigments in the intertidal green alga Ulva lactuca L. Planta 215, 502-509.

69. Roleda, M. Y., D. Hanelt and C. Wiencke (2005) Growth kinetics related to physiological parameters in young Saccorhiza dermatodea and Alaria esculenta sporophytes exposed to UV radiation. Polar Biol. 28, 539-549.

70. Roleda, M. Y., C. Wiencke and D. Hanelt (2006) Thallus morphology and optical characteristics affect growth and DNA damage by UV radiation in juvenile Arctic Laminaria sporophytes. Planta 223, 407-417.

71. Roleda, M. Y., D. Hanelt and C. Wiencke (2006) Growth and DNA damage in young Laminaria sporophytes exposed to ultraviolet radiation: Implication for depth zonation of kelps on Helgoland (North Sea). Mar. Biol. 148, 1201-1211.

72. Aguilera, J., K. Bischof, U. Karsten, D. Hanelt and C. Wiencke (2002) Seasonal variation in ecophysiological patterns in macroalgae from an Arctic fjord. II. Pigment accumulation and biochemical defence systems against high light stress. Mar. Biol. 140, 1087-1095.

73. Roy, S. (2000) Strategies for the minimisation of UV-induced damage. In The Effects of UV Radiation in the Marine Environment (Edited by S. de Mora, S. Demers and M. Vernet), pp. 177-205. Cambridge University Press, Cambridge.

74. Buckley, C. E. and J. A. Houghton (1976) A study of the effects of near UV radiation on the pigmentation of the blue-green alga Gloeocapsa alpicola. Arch. Microbiol. 107, 93-97.

75. Goes, J. I., N. Handa, S. Taguchi and T. Hama (1994) Effect of UV-B radiation on the fatty acid composition of the marine phytoplankter Tetraselmis sp.: Relationship to cellular pigments. Mar. Ecol. Prog. Ser. 114, 259-274.

76. Pascal, A., C. Gradinaru, U. Wacker, E. Peterman, F. Calkoen, K.-D. Irrgang, P. Horton, G. Renger, R. van Grondelle, B. Robert and H. van Amerongen (1999) Spectroscopic characterization of the spinach Lhcb4 protein (CP29), a minor light-harvesting complex of photosystem II. Eur. J. Biochem. 262, 817823.

77. Croce, R., G. Cinque, A. R. Holzwarth and R. Bassi (2000) The Soret absorption properties of carotenoids and chlorophylls in antenna complexes of higher plants. Photosyn. Res. 64, 221-231.

78. Roleda, M. Y., M. N. Clayton and C. Wiencke (2006) Screening capacity of UV-absorbing compounds in spores of Arctic Laminariales. J. Exp. Mar. Biol. Ecol. 338, 123-133.

79. Schoenwaelder, M. E. A. and M. N. Clayton (1998) Secretion of phenolic substances into the zygote wall and cell plate in embryos of Hormosira and Acrocarpia (Fucales, Phaeophyceae). J. Phycol. 34, 969-980.

80. Schoenwaelder, M. E. A. and M. N. Clayton (1998) The secretion of phenolic compounds following fertilization in Acrocarpia paniculata (Fucales, Phaeophyta). Phycologia 37, 40-46.
81. Schoenwaelder, M. E. A. and M. N. Clayton (2000) Physode formation in embryos of Phyllospora comosa and Hormosira banksii (Phaeophyceae). Phycologia 39, 1-9.

82. Henry, B. E. and K. L. van Alstyne (2004) Effects of UV radiation on growth and phlorotannins in Fucus gardneri (Phaeophyceae) juveniles and embryos. J. Phycol. 40, 527-533.

83. Pavia, H., G. Cervin, A. Lindgren and P. Aberg (1997) Effects of UV-B radiation and simulated herbivory on phlorotannins in the brown alga Ascophyllum nodosum. Mar. Ecol. Prog. Ser. 157, 139-146.

84. Roleda, M. Y., C. Wiencke and U. H. Lüder (2006) Impact of ultraviolet radiation on cell structure, UV-absorbing compounds, photosynthesis, DNA damage and germination in zoospores of Arctic Saccorhiza dermatodea. J. Exp. Bot. 57, 3847-4856.

85. Garcia-Pichel, F. (1994) A model for internal self-shading in planktonic organisms and its implications for the usefulness of ultraviolet sunscreens. Limnol. Oceanogr. 39, 1704-1717.

86. Swanson, A. K. and L. D. Druehl (2002) Induction, exudation and the UV protective role of kelp phlorotannins. Aquat. Bot. 73, 241-253.

87. Franklin, L. A. and R. M. Forster (1997) The changing irradiance environment: Consequences for marine macrophyte physiology, productivity and ecology. Eur. J. Phycol. 32, 207-232.

88. Caldwell, M. M., R. Robberecht and S. D. Flint (1983) Internal filters: Prospects for UV-acclimation in higher plants. Physiol. Plant. 58, 445-450.

89. Lüder, U. H. and M. N. Clayton (2004) Induction of phlorotannins in the brown algae Ecklonia radiata (Laminariales, Phaeophyta) in response to simulated herbivory-The first microscopic study. Planta 218, 928-937.

90. Shibata, T., S. Kawaguchi, Y. Hama, M. Inagaki, K. Yamaguchi and T. Nakamura (2004) Local and chemical distribution of phlorotannins in brown algae. J. Appl. Phycol. 16, 291-296.

91. Roleda, M. Y. (2006) Effects of ultraviolet radiation on early life stages of cold temperate and Arctic macroalgae: Implications for recruitment and vertical depth distribution. Ber. Polar Meeresforsch. 526, 1-176.

92. Long, A. and R. E. Michod (1995) Origin of sex for error repair I. Sex, diploidy, and haploidy. Theor. Popul. Biol. 47, 18-55.

93. Pakker, H., R. S. T. Martins, P. Boelen, A. G. J. Buma, O. Nikaido and A. M. Breeman (2000) Effects of temperature on the photoreactivation of ultraviolet-B-induced DNA damage in Palmaria palmata (Rhodophyta). J. Phycol. 36, 334-341.

94. Wiencke, C., I. Gómez, H. Pakker, A. Flores-Moya, M. Altamirano, D. Hanelt, K. Bischof and F.-L. Figueroa (2000) Impact of UV radiation on viability, photosynthetic characteristics and DNA of brown algal zoospores: Implications for depth zonation. Mar. Ecol. Prog. Ser. 197, 217-229.

95. Dring, M. J., V. Makarov, E. Schoschina, M. Lorenz and K. Lüning (1996) Influence of ultraviolet-radiation on chlorophyll fluorescence and growth in different life-history stages of three species of Laminaria (Phaeophyta). Mar. Biol. 126, 183-191.

96. Caldwell, M. M., A. H. Teramura, M. Tevini, J. F. Bornman, L. O. Björn and G. Kulandaivelu (1995) Effects of increased solar ultraviolet radiation on terrestrial plants. Ambio 24, 166-173.

97. Rozema, J., J. van de Staaij, L. O. Björn and M. Caldwell (1997) UV-B as an environmental factor in plant life: Stress and regulation. Trends Ecol. Evol. 12, 22-28.

98. Warner, C. W. and M. M. Caldwell (1983) Influence of photon flux density in the $400-700 \mathrm{~nm}$ waveband on inhibition of photosynthesis by UV-B $(280-320 \mathrm{~nm})$ irradiation in soybean leaves: Separation of indirect and direct effects. Photochem. Photobiol. 38, 341-346.

99. Aguilera, J., U. Karsten, H. Lippert, B. Vögele, E. Philipp, D. Hanelt and C. Wiencke (1999) Effects of solar radiation on growth, photosynthesis and respiration of marine macroalgae from the Arctic. Mar. Ecol. Prog. Ser. 191, 109-119.

100. Michler, T., J. Aguilera, D. Hanelt, K. Bischof and C. Wiencke (2002) Long-term effects of ultraviolet radiation on growth and photosynthetic performance of polar and cold-temperate macroalgae. Mar. Biol. 140, 1117-1127.

101. Cline, M. G. and F. B. Salisbury (1966) Effects of ultraviolet radiation on the leaves of higher plants. Radiat. Bot. 6, 151-163. 
102. Robberecht, R. and M. M. Caldwell (1978) Leaf epidermal transmittance of ultraviolet radiation and its implications for plant sensitivity to ultraviolet-radiation induced injury. Oecologia (Berl.) 32, 277-287.

103. Barnes, P. W., S. D. Flint and M. M. Caldwell (1990) Morphological responses of crop and weed species of different growth forms to ultraviolet-B radiation. Am. J. Bot. 77, 1354-1360.

104. Carr, G. M., H. C. Duthie and W. D. Taylor (1997) Models of aquatic plant productivity: A review of the factors that influence growth. Aquat. Bot. 59, 195-215.

105. Long, S. P., S. Humphries and P. G. Falkowski (1994) Photoinhibition of photosynthesis in nature. Annu. Rev. Plant Physiol. Plant Mol. Biol. 45, 633-662.

106. Chapman, A. R. O. (1984) Reproduction, recruitment and mortality in two species of Laminaria in southwest Nova Scotia. J. Exp. Mar. Biol. Ecol. 78, 99-109.

107. Lüning, K. (1980) Control of algal life-history by daylength and temperature. In The Shore Environment, Vol. 2 (Edited by J. H.
Price, D. E. G. Irvine and W. F. Farnham), pp. 915-945. Academic Press, New York.

108. Santelices, B. (1990) Patterns of reproduction, dispersal and recruitment in seaweeds. Oceanogr. Mar. Biol. Annu. Rev. 28, 177-276.

109. Kinlan, B. P., M. H. Graham, E. Sala and P. K. Dayton (2003) Arrested development of giant kelp (Macrocystis pyrifera, Phaeophyceae) embryonic sporophytes: A mechanism for delayed recruitment in perennial kelps? J. Phycol. 39, 47-57.

110. Hoffman, J. R., L. J. Hansen and T. Klinger (2003) Interactions between UV radiation and temperature limit inferences from single-factor experiments. J. Phycol. 39, 268-272.

111. Altamirano, M., A. Flores-Moya and F.-L. Figueroa (2003) Effects of UV radiation and temperature on growth of germlings of three species of Fucus (Phaeophycea). Aquat. Bot. 75, 9-20. 